\title{
Packaging Materials Problem
}

National Cancer Institute

\section{Source}

National Cancer Institute. Packaging Materials Problem. NCI Thesaurus. Code C139505.

Problems that occurred because of the composition or type of packaging materials was inappropriate for the device. 